\title{
EVALUASI PENERAPAN AKUNTANSI PERSEDIAAN OBAT UNTUK PENENTUAN HARGA POKOK PENJUALAN PADA PT. CEMPAKA INDAH MURNI MANADO
}

\author{
Maissy P. Sandiri ${ }^{1}$, Ventje Ilat $^{2}$, Sherly Pinatik ${ }^{3}$ \\ 1,2,3 Jurusan Akuntansi, Fakultas Ekonomi dan Bisnis Universitas Sam Ratulangi, J1. Kampus Bahu, Manado, \\ 95115, Indonesia \\ E-mail: maissysandiri@gmail.com
}

\begin{abstract}
Inventory is very important for the survival of the company, the company must be able to estimate the amount of inventory it supplies. This study aims to determine evaluation the application of drug inventory accounting for the determination of cost of goods sold at PT. Cempaka Indah Murni Manado which is engaged in the distribution of medicines. The application of drug inventory accounting conducted by PT. Cempaka Indah Murni Manado is suitable but the company does not recognize incoming transfers because the products sold at PT. Cempaka Indah Murni Manado was sent from the head office in Surabaya. The results of the research on the stock accounting report for inventory from January to December most of the items there are differences in selling price and incoming transfers every month. The analytical method used in this study is a qualitative descriptive method and conclusions are drawn from the recording its merchandise inventory is a computerized perpetual method, while for the method of determining the cost of inventory using the FIFO (First In First Out) method.
\end{abstract}

Keywords: Inventory accounting, cost of goods sold

\section{PENDAHULUAN}

Persediaan merupakan salah satu aset yang ada diperusahan dan diperlukan pencatatan dan penilaian. Umumnya persediaan mempunyai nilai yang cukup besar dari aktiva lancar. PT. Cempaka Indah Murni Manado merupakan perusahaan dagang yang cukup besar yang bergerak dalam bidang distributor obat-obatan. Pusat PT. Cempaka Indah Murni Manado berada di Surabaya yang juga melakukan aktivitas yang sama yaitu melakukan transaksi penjualan obat-obatan. Dalam kelangsungan aktivitas usahanya perusahaan membutuhkan persediaan obat yang jumlahnya tidak sedikit. Apalagi perusahaan melakukan kegiatan jual beli secara terus menerus sehingga kualitas obat sangat penting dan harus diperhatikan oleh perusahaan.

Persediaan barang dagangan di PT. Cempaka Indah Murni Manado memakai Metode FIFO yaitu barang masuk pertama adalah barang dijual pertama. Metode yang dipakai di PT. Cempaka Indah Murni Manado konsisten dengan aliran fisik persediaan, karena dalam penjualannya PT. Cempaka Indah Murni Manado menggunakan metode FIFO. Untuk perhitungan harga maka digunakan harga dari stock barang dari transaksi yang terdahulu. Sebagai perusahaan perdagangan ada masalah-masalah yang dihadapi. Saat melakukan kegiatan, sering terdapat perbedaan jumlah fisik barang yang ada dalam gudang dengan pencatatan persediaan pada bagian akuntansi, penyebabnya karena pengawasan dan koordinasi yang kurang dari pihak gudang dan bagian akuntansi dalam mencatat persediaan. Selain itu, sering pula terjadi pengembalian obat dari pelanggan atau return sehingga jumlah hpp jadi lebih besar sedangkan laba bersih dilaporan laba rugi jadi lebih kecil dari jumlah sesungguhnya. 


\section{TINJAUAN PUSTAKA}

Akuntansi. Romney (2015:11), akuntansi adalah proses identifikasi, penyimpanan, pengumpulan data dan proses komunikasi, pengembangan, dan pengukuran.

Siklus Akuntansi. Menurut Rahman Pura (2016:18) pengertian siklus akuntansi adalah kegiatan akuntansi yang didalamnya terdapat pencatatan akuntansi sampai tutup buku.

Akuntansi Keuangan. Akuntansi keuangan merupakan bentuk laporan keuangan yang dimanfaatkan pihak eksternal dan internal dalam perusahaan untuk pengambilan keputusan berdasarkan pada Standar Akuntansi Keuangan (SAK) yang berlaku (Waluyo, 2016:34).

Laporan Keuangan. Reeve (2018:22) mendefinisikan laporan keuangan adalah laporan akuntansi yang didalamnya terdapat informasi keuangan mengenai kondisi suatu perusahaan.

Akuntansi Persediaan. Aset perusahaan dalam bentuk perlengkapan atau barang yang didapat untuk mendukung kegiatan operasional pemerintah atau barang yang akan dijual kepada masyarakat dalam suatu periode.

Persediaan. Menurut Mulyadi (2016:99) mendefinisikan persediaan adalah barang yang dibeli untuk dijual kembali oleh perusahaan (barang dagangan), atau barang yang masih dalam proses produksi dan selanjutnya diolah menjadi barang jadi kemudian barang tersebut dijual (barang dalam proses) atau digunakan dalam proses produksi barang jadi lalu dijual (bahan baku/ pembantu).

\section{Tujuan Akuntansi Persediaan}

1. Memberikan informasi mengenai persediaan mulai dari pengakuan sampai proses penerimaanya dengan prosedur yang baku.

2. Memberikan informasi mengenai alur persediaan yang ada sehingga dapat memperhitungkan tingkat pengendalian yang diperlukan.

3. Pengendalian persediaan dapat diperhitungkan secara ekonomis keberadaanya.

Jenis-jenis Persediaan. Menurut Mulyadi (2016: 99) jenis persediaan barang dagang terdapat pada perusahaan dagang yang kegiatannya beli dan jual barang. Sedangkan perusahaan manufaktur kegiatannya mengelolah bahan baku menjadi barang jadi, terdapat jenis persediaan bahan baku/pembantu, barang dalam proses dan barang jadi.

Metode Perhitungan Harga Pokok Persediaan. Menurut Kartikahadi (2016: 298) adapun metode perhitungan harga pokok persediaan, diantaranya : Rata-rata (Average), MPKP (First In First Out-FIFO), dan MTKP (Last In First Out -LIFO).

Metode Pencatatan Persediaan. Menurut Mulyadi (2016: 100-101) ada dua metode pencatatan persediaan, yaitu : Fisik dan Perpetual.

Harga Pokok Penjualan. HPP (harga pokok penjualan) adalah harga perolehan dari barang yang dijual.

\section{Manfaat Perhitungan Harga Pokok Penjualan}

1. Patokan dalam menentukan harga jual suatu barang.

2. Mengetahui laba suatu perusahaan. Jika harga jual lebih tinggi dari hpp maka diperoleh laba, dan sebaliknya apabila harga jual lebih rendah dari hpp akan diperoleh kerugian.

\section{Komponen Harga Pokok Penjualan}

1. Persediaan awal barang dagangan

2. Persediaan akhir barang dagangan

3. Pembelian bersih

\section{Perhitungan Harga Pokok Penjualan}

Persediaan awal barang dagangan

Pembelian

$\mathrm{XXX}$

Beban angkut pembelian

$\underline{\mathrm{XXX}(+)}$

Retur pembelian

\section{$\mathrm{XXX}$}

Potongan pembelian

$\underline{\mathrm{XXX}(+)}$ 
Jumlah pembelian bersih

\section{$\underline{\mathrm{XXX}(-)}$}

Barang tersedia untuk dijual

$\frac{\mathrm{XXX}(+)}{\mathrm{XXX}}$
$\mathrm{XXX}(-)$
$\mathbf{X X X}$

Persediaan akhir barang dagangan

Harga pokok penjualan

$\mathbf{X X X}$

Penelitian Terdahulu. Karongkong (2018) dengan judul Penerapan Akuntansi Persediaan Barang Dagang Pada UD. Muda-Mudi Toli-Toli. Hasil penelitian menunjukkan UD. MudaMudi telah menerapkan berdasarkan akuntabel untuk manajemen inventaris mereka tetapi masih memerlukan perbaikan tentang penyediaan pembagian beban kerja untuk masuk dan menyimpan barang dan penghasilan. Wullur (2016) dengan judul Analisis Penerapan Akuntansi Persediaan Berdasarkan PSAK no. 14 Pada PT. Gatraco Indah Manado. Hasil penelitian menunjukkan bahwa perusahaan telah sesuai dengan standar akuntansi.

\section{METODE PENELITIAN}

Jenis Penelitian. Dalam penelitian mengunakan pendekatan kualitatif, penelitian dilakukan bersifat deskriptif untuk mengetahui kenyataan dari kejadian yang diteliti sehingga memudahkan penulis untuk mendapatkan data yang objektif dalam rangka mengetahui dan memahami Evaluasi Penerapan Akuntansi Persediaan Obat Untuk Penentuan Harga Pokok Penjualan yang diterapkan oleh PT. Cempaka Indah Murni Manado.

Tempat dan Waktu Penelitian. Penelitian dilakukan pada PT. Cempaka Indah Murni Manado yang bertempat di Jl. Raya Sea No. 140, Lingkungan V, Malalayang 1 Barat, Manado - 95262. Waktu penelitian dimulai dari bulan Maret sampai dengan waktu yang disesuaikan dengan kebutuhan penelitian.

\section{Prosedur Penelitian}

1. Meminta izin melakukan penelitian pada PT. Cempaka Indah Murni Manado.

2. Mengetahui struktur organisasi pada PT. Cempaka Indah Murni Manado dan tugas, tanggung jawab masing-masing.

3. Mencari tau bagian di perusahaan yang bertanggung jawab dengan laporan keuangan yang hubungannya dengan persediaan barang dagang.

4. Menelusuri proses penerapan akuntansi persediaan barang dagang untuk penentuan harga pokok penjualan yang ada di PT. Cempaka Indah Murni Manado.

5. Menarik suatu kesimpulan, saran untuk PT. Cempaka Indah Murni Manado.

\section{Metode Pengumpulan Data}

Jenis Data. Data yang dipakai dipenelitian ini adalah data kualitatif yang diperoleh melalui wawancara, observasi, diskusi atau pengamatan.

Sumber Data. Sumber data yang diambil adalah data primer yang memberikan data langsung kepada peneliti dan data sekunder yang didapat dari dokumen.

Teknik Pengumpulan Data. Dilakukan dengan cara:

1. Observasi

2. Tinjauan kepustakaan

3. Wawancara

Metode Analisis Data. Analisis data yang dipakai pada penelitian ini yakni deskriptif kualitatif yaitu membandingkan, menganalisis data yang di dapat dari PT. Cempaka Indah Murni Manado. Dengan digunakannya metode tersebut, dapat memberikan informasi dan bisa ditarik kesimpulan.

\section{HASIL PENELITIAN DAN PEMBAHASAN}

4.1. Hasil Penelitian

Produk Obat-obatan. Perusahaan mengelompokkan produk obat-obatan ke dalam beberapa kelompok besar yaitu : Alumy, Demacolin, Cerebrofort, Cap lang, Paraco 


\begin{tabular}{|c|c|c|c|}
\hline \multicolumn{4}{|c|}{ Jenis-jenis Persediaan Obat-obatan } \\
\hline No & Nama Barang & Satuan & Harga \\
\hline 1 & Alumy syrup $100 \mathrm{ml}$ & $\mathrm{Btl}$ & Rp. 6.000 \\
\hline 2 & Alumy tablet (24's) & Box & Rp. 38.500 \\
\hline 3 & Balsem Otot Geliga $40 \mathrm{gr}$ & Btl & Rp. $10.766,67$ \\
\hline 4 & Balsem Otot Geliga $20 \mathrm{gr}$ & Btl & Rp. $5.462,50$ \\
\hline 5 & Balsem Otot Geliga $10 \mathrm{gr}$ & Btl & Rp. $3.008,33$ \\
\hline 6 & Balsem Lang $40 \mathrm{gr}$ & Btl & Rp. $10.766,67$ \\
\hline 7 & Balsem Lang $20 \mathrm{gr}$ & Btl & Rp. $\quad 5.462,50$ \\
\hline 8 & Balsem Lang $10 \mathrm{gr}$ & Btl & Rp. 2.850 \\
\hline 9 & Cerebrofort Gold & Btl & Rp. 23.280 \\
\hline 10 & Cerebrofort Gold Orange & Btl & Rp. 12.960 \\
\hline 11 & Cerebrofort Gold Strawberry & Btl & Rp. 12.960 \\
\hline 12 & Demacolin syrup $60 \mathrm{ml}$ & Btl & Rp. 7.200 \\
\hline 13 & Demacolin 100's & Box & Rp. 22.000 \\
\hline 14 & Minyak Kayu Putih FS 210 ml & Btl & Rp. $41.245,83$ \\
\hline 15 & Minyak Kayu Putih 120 ml & Btl & Rp. $23.908,33$ \\
\hline 16 & Minyak Kayu Putih 60 ml & Btl & Rp. $12.666,67$ \\
\hline 17 & Minyak Kayu Putih 30 ml & Btl & Rp. 6.650 \\
\hline 18 & Minyak Kayu Putih 15 ml & Btl & Rp. $3.641,67$ \\
\hline 19 & MKP Aromaterapi $210 \mathrm{ml}$ & Btl & Rp. $41.245,83$ \\
\hline 20 & MKP Aromaterapi $120 \mathrm{ml}$ & Btl & Rp. $23.908,33$ \\
\hline 21 & MKP Aromaterapi $60 \mathrm{ml}$ & Btl & Rp. $12.666,67$ \\
\hline 22 & MKP Aromaterapi $30 \mathrm{ml}$ & Btl & Rp. $\quad 6.650$ \\
\hline 23 & MKP Aromaterapi $15 \mathrm{ml}$ & Btl & Rp. $3.641,67$ \\
\hline 24 & Minyak Telon 100 ml & Btl & Rp. $17.258,33$ \\
\hline 25 & Minyak Telon $60 \mathrm{ml}$ & Btl & Rp. $11.083,33$ \\
\hline 26 & Minyak Telon $30 \mathrm{ml}$ & Btl & Rp. $\quad 6.095,83$ \\
\hline 27 & Minyak Telon $15 \mathrm{ml}$ & Btl & Rp. $3.404,17$ \\
\hline 28 & Minyak Telon Plus $60 \mathrm{ml}$ & Btl & Rp. $11.558,33$ \\
\hline 29 & Minyak Telon Plus $30 \mathrm{ml}$ & Btl & Rp. $\quad 6.491,67$ \\
\hline 30 & Paraco tab 240 (24’s) & Box & Rp. 28.000 \\
\hline 31 & Paraco syrup & Btl & Rp. 10.700 \\
\hline
\end{tabular}

Metode Perhitungan Harga Pokok Persediaan. Metode perhitungan harga pokok persediaan pada PT. Cempaka Indah Murni Manado menggunakan sistem perpetual dengan metode FIFO atau Masuk Pertama Keluar Pertama dimana barang yang pertama kali dibeli adalah barang yang pertama dijual, karena persediaan yang terjual terdapat harga perolehan dari barang yang masuk pertama, jadi harga perolehan persediaan barang yang tersisa terdiri dari harga perolehan dari persediaan yang masuk terakhir.

Metode Pencatatan Persediaan. Metode pencatatan yang digunakan PT. Cempaka Indah Murni adalah perpetual yang terkomputerisasi. PT. Cempaka Indah Murni Manado memiliki pencatatan persediaan meliputi penjualan, transfer masuk barang. 


\section{Pengungkapan}

Laporan Laba/Rugi PT. Cempaka Indah Murni Manado

PT. Cempaka Indah Murni Manado

Laba Rugi

Untuk Periode Berakhir 31 Desember 2016

Penjualan

Rp. 4.093.943.609,42

Harga Pokok Penjualan :

Persediaan Awal

Rp. $\quad 364.968 .192,77$

Transfer Masuk

Rp. 3.644.015.532,88(+)

Barang yang tersedia untuk dijual

Rp. 4.008.983.725,65

Persediaan Akhir

Rp. 4.545.312.312,68(-)

Total Harga Pokok Penjualan

Rp.536.328.587,03(-)

Laba Kotor

Rp. 3.557.615.022,39

Laporan Keuangan (Neraca) PT. Cempaka Indah Murni Manado

PT. Cempaka Indah Murni Manado

Neraca

Per 31 Desember 2016

\section{Aktiva}

Aktiva Lancar

Kas

Piutang Dagang

Persediaan

Total Aktiva Lancar

Aktiva Tetap

Peralatan

Akum Penyusutan Peralatan

Gedung

Akum Penyusutan Gedung

Total Aktiva Tetap

Total Aktiva

\section{Kewajiban}

Hutang Lancar

Hutang Dagang

Hutang Lain-lain

Hutang Pajak

Total Hutang

Modal

Total Modal

Total Kewajiban
Rp.1.717.258.014,42

Rp.2.574.747.083,21

Rp. 4.545.312.312,68(+)

Rp.8.837.317.410,31
Rp. XXX

Rp. (XXX)

Rp. XXX

Rp. (XXX)

Rp. XXX

Rp. 8.837.317.410,31
Rp. XXX

Rp. XXX

Rp. XXX

Rp. XXX (+)

Rp. XXX

$\underline{\text { Rp.XXX }}$

Rp.XXX

\subsection{Pembahasan}

Sebagian besar produk yang diproduksi PT. Cempaka Indah Murni Manado berasal dari kantor pusat PT. Cempaka Indah Murni di Surabaya. Barang yang dijual PT. Cempaka Indah Murni Manado tidak dibeli dari produsen tapi ditransfer dari kantor pusat untuk dijual ke daerah Sulawesi Utara. Penerapan akuntansi persediaan obat yang ada di PT. Cempaka Indah Murni Manado untuk penentuan harga pokok penjualan sudah sesuai tapi perusahaan tidak mengakui adanya pembelian dan biaya angkut, perusahaan hanya mengakui adanya 
transfer masuk karena produk yang di jual di PT. Cempaka Indah Murni Manado ditransfer dari kantor pusat. Dari hasil penelitian, bulan Januari sampai Desember 2016 di laporan stok akuntansi persediaan, sebagian besar barang terdapat perbedaan harga jual dan transfer masuk barang tiap bulannya. Pencatatan persediaan yang digunakan PT. Cempaka Indah Murni dapat dijelaskan menggunakan metode perpetual yang terkomputerisasi. Untuk menentukan harga pokok penjualan digunakan metode FIFO. Persediaan di PT. Cempaka Indah Murni Manado dapat dilihat lewat aktiva lancar pada bagian neraca untuk jumlah persediaan dan lewat laporan laba rugi untuk biaya.

\section{KESIMPULAN DAN SARAN}

\subsection{Kesimpulan}

Kesimpulan yang diambil yaitu:

1. PT. Cempaka Indah Murni Manado menerapkan metode pencatatan dengan menggunakan Metode Perpetual yang terkomputerisasi dan untuk menghitung harga pokok penjualan menggunakan metode FIFO.

2. Pengungkapan persediaan pada PT. Cempaka Indah Murni Manado dapat disajikan melalui laporan keuangan yaitu laporan laba rugi dan neraca.

3. Penerapan akuntansi persediaan obat untuk penentuan harga pokok penjualan di PT. Cempaka Indah Murni Manado sudah sesuai.

\subsection{Saran}

Saran yang dapat diberikan adalah :

1. Diakhir tahun setiap perusahaan melakukan stock opname terhadap semua jenis persediaan barang dengan maksud melakukan pengecekan pada catatan persediaan dan memastikan saldo yang dicatat di bagian akuntansi atau pembukuan. Hal ini dimaksudkan untuk melihat apakah catatan persediaan di bagian pembukuan dengan bagian gudang melalui perhitungan fisik sudah sama, sehingga perusahaan dapat mencari perbedaan dalam jumlah persediaan dan tidak terjadi pencatatan double entry.

2. Sebuah perusahaan sebaiknya menggunakan metode FIFO dalam perhitungan laba karena metode ini lebih baik dibanding dengan metode Weighted Average dan LIFO karena dapat menghasilkan laba yang besar sehingga bisa menarik investor untuk investasi.

\section{DAFTAR PUSTAKA}

Karongkong, Kenny. 2018. Penerapan Akuntansi Persediaan Barang Dagang Pada UD. Muda-Mudi Toli-Toli. Fakultas Ekonomi dan Bisnis, Jurusan Akuntansi Universitas Sam Ratulangi Manado.

Kartikahadi. 2016. Akuntansi Keuangan Berdasarkan SAK Berbasis IFRS. Jakarta: Salemba Empat.

Mulyadi. 2016. Akuntansi Biaya. Yogyakarta: UPP Sekolah Tinggi Ilmu Ekonomi YKPN. 2016. Sistem Akuntansi (Ed. Ke-3). Jakarta: Salemba Empat.

Pura, Rahman. 2016. Pengantar Akuntansi 1 Pendekatan Siklus Akuntansi, Penerbit Erlangga, Jakarta.

Reeve, James. 2018. Pengantar Akuntansi 2 (Adaptasi Indonesia). Edisi 4. Salemba Empat. Jakarta.

Romney, Marshall. 2015. Sistem Informasi Akuntansi (Ed. Ke-13). Jakarta: Salemba Empat.

Waluyo. 2016. Akuntansi Pajak. Salemba Empat, Jakarta.

Wullur, Tesalonika. 2016. Analisis Penerapan Akuntansi Persediaan Berdasarkan PSAK No. 14 Pada PT. Gatraco Indah Manado. Universitas Sam Ratulangi Manado. 